Elsevier

TOXLett. 1260

\title{
BINDING OF CARBON TETRACHLORIDE METABOLITES TO RAT HEPATIC MITOCHONDRIAL DNA
}

(Carbon tetrachloride metabolism; mitochondrial DNA; mitochondrial metabolism; DNA binding)

\section{GERALD N. LEVY and MICHAEL J. BRABEC*}

Toxicology Program, Department of Environmental and Industrial Health, School of Public Health, The University of Michigan, Ann Arbor, MI 48109 (U.S.A.)

(Received September 16th, 1983)

(Revision received February 27th, 1984)

(Accepted April 18th, 1984)

\section{SUMMARY}

Radioactivity from $\left[{ }^{14} \mathrm{C}\right] \mathrm{CCl}_{4}$ was bound to highly purified mitochondrial DNA (mtDNA) and nuclear DNA (nDNA) prepared from livers of rats after a single dose of $\left[{ }^{14} \mathrm{C}_{\mathrm{CCl}}\right.$. At a low, non-necrotizing dose as well as at an acutely toxic dose, mtDNA bound 20-50-fold more radioactivity per mg than did nDNA. Extensive enzymatic digestion and purification of mtDNA did not remove radioactivity. Binding of radioactivity to mtDNA could also be demonstrated after anaerobic incubation of isolated mitochondria with $\left[{ }^{14} \mathrm{C}_{\mathrm{CCl}}, \mathrm{NADPH}, \mathrm{ADP}\right.$, and succinate. Our results suggest that $\mathrm{CCl}_{4}$ can be activated by rat hepatic mitochondrial enzymes to metabolites which bind covalenty to mtDNA.

\section{INTRODUCTION}

The covalent binding of chemical carcinogens to nDNA is usually considered to be a crucial step in the malignant transformation of cells. Recently, several reports have shown that mtDNA can also be a site of carcinogen binding. Chemical carcinogens that show significant binding to mtDNA include BPDE [1], several polycyclic aromatic hydrocarbons [2], aflatoxin $B_{1}$ [3], and benzene [4]. Metabolic transformation of the xenobiotic within the mitochondrion followed by binding to mtDNA has been suggested for aflatoxin $B_{1}[5]$ and benzene [4].

\footnotetext{
${ }^{*}$ To whom correspondence should be addressed.
}

Abbreviations: BPDE, dihydrodiol-epoxide derivative of benzo(a)pyrene; SDS, sodium dodecyl sulfate. 
$\mathrm{CCl}_{4}$ metabolites have been shown to bind to nDNA, proteins, and lipids [6]. Previous studies of rat hepatic mitochondria showed that an increase in the rate of synthesis of mtDNA and a decrease in mtDNA turnover produces an increase in the total amount of mtDNA in the liver after acute $\mathrm{CCl}_{4}$ intoxication [7]. The rate of synthesis and total amount of mtDNA return to normal values following recovery.

These data suggest the possibility of direct interaction between $\mathrm{CCl}_{4}$ and mtDNA. This study examined the binding of radioactivity from $\left[{ }^{14} \mathrm{C}\right] \mathrm{CCl}_{4}$ to hepatic mtDNA following either exposure of rats to $\left[{ }^{14} \mathrm{C}_{\mathrm{CCCl}}\right.$, or the incubation of isolated rat hepatic mitochondria with $\left[{ }^{14} \mathrm{C}_{\mathrm{CCl}}\right.$.

\section{METHODS}

\section{Chemicals}

$\left[{ }^{14} \mathrm{C}_{\mathrm{CCCl}}\right.$ (spec. act. $26.9 \mathrm{mCi} / \mathrm{mmol}$ and $>99 \%$ radiochemical purity) was purchased from Amersham. $\mathrm{CsCl}$, ethidium bromide, RNase (type 1-A) and protease (Streptomyces griseus) were purchased from Sigma Chemical Co., St. Louis, MO. Other chemicals were highest grade commercially available.

\section{Animals and treatment}

Male Sprague-Dawley rats (Charles River, Portage, MI) wcighing 220-280 g werc used. Animals were fasted $16 \mathrm{~h}$ before use, with drinking water available ad lib.

A single dose of $\mathrm{CCl}_{4}$ at either non-necrotizing $\left(2 \mu \mathrm{l} / \mathrm{kg}=2.1 \cdot 10^{-2} \mu \mathrm{mol} / \mathrm{kg}\right)$ or acutely toxic $(1.1 \mathrm{ml} / \mathrm{kg}=11.4 \mathrm{mmol} / \mathrm{kg})$ level was administered. The low dose was diluted in corn oil to a volume of $200 \mu \mathrm{l}$. The labelled $\mathrm{CCl}_{4}$ was diluted with unlabelled $\mathrm{CCl}_{4}$ to give a specific activity of $0.048 \mathrm{mCi} / \mathrm{mmol}$. At $5 \mathrm{~h}$ and $24 \mathrm{~h}$ after the low, and at $24 \mathrm{~h}$ after the high dose, pairs of rats were killed by decapitation and mitochondrial and nuclear fractions of the liver prepared following the procedure described by Brabec et al. [7].

Hepatic nDNA was prepared by dissociation of an aliquot of the nuclear fraction in 2\% SDS, repeated extraction with chloroform-isoamyl alcohol (20:1) and sequential digestion with RNase and protease. Enzyme treatment was followed by further extractions and 2 cycles of ethanol precipitation. The purified nDNA was dissolved in $0.15 \mathrm{M} \mathrm{NaCl}$ and $0.01 \mathrm{M}$ sodium phosphate, $\mathrm{pH}$ 7.2.

Hepatic mtDNA was prepared from the isolated washed mitochondria after lysis in $10 \mathrm{mM}$ Tris (pH 7.5), $1 \mathrm{mM}$ EDTA, $1 \%$ SDS at $37^{\circ} \mathrm{C}$, and extracted 5 times with chloroform-isoamyl alcohol (20:1). The aqueous phase was brought to a density of $1.56 \mathrm{~g} / \mathrm{cm}^{3}$ with $\mathrm{CsCl}$ and ethidium bromide added to $400 \mu \mathrm{g} / \mathrm{ml}$ for centrifugation in a Spinco SW 41 rotor at $20^{\circ}$ for $40 \mathrm{~h}$ at $36000 \mathrm{rev} . / \mathrm{min}$. The gradient was fractionated by collecling drops. Aliquots of every other fraction were counted for radioactivity.

The alternate radioactive fractions were pooled and extracted with isoamyl alcohol until free of ethidium bromide, then dialyzed against $0.15 \mathrm{M} \mathrm{NaCl}, 0.01 \mathrm{M}$ sodium phosphate, pH 7.2. 


\section{Incubation of isolated mitochondria}

Mitochondria were prepared from livers of untreated rats as described [8]. Additionally, a post-mitochondrial supernatant fraction was prepared by homogenizing $2 \mathrm{~g}$ of liver in $3 \mathrm{ml}$ of incubation media $(0.25 \mathrm{M}$ sucrose, $1 \mathrm{mM}$ EDTA, $10 \mathrm{mM}$ Tris, $10 \mathrm{mM} \mathrm{KCl}, \mathrm{pH} 7.2$ ), and centrifuging at $10000 \times \mathrm{g}$ for $20 \mathrm{~min}$. The postmitochondrial supernatant containing the endoplasmic reticulum was included as a source of activating enzymes in the incubation.

Pooled mitochondria from 2 to 4 rats were suspended in incubation media using $1 \mathrm{ml}$ for each $2 \mathrm{~g}$ of original liver, wet weight. When present, the concentration of calf thymus DNA was $2 \mathrm{mg} / \mathrm{ml}$.

Mitochondrial suspension $(2.5 \mathrm{ml})$ or nuclear DNA solution $(2.5 \mathrm{ml})$ plus either $0.5 \mathrm{ml}$ post-mitochondrial supernatant, or $0.5 \mathrm{ml}$ incubation media, were incubated under nitrogen with $1 \mathrm{mM} \mathrm{NADPH}$ and $3 \mathrm{mM}$ glutathione [9]. To assure anaerobic conditions, the mitochondrial incubations were made $10 \mathrm{mM}$ in succinate, $3 \mathrm{mM}$ in $\mathrm{ADP}$, and kept at $37^{\circ} \mathrm{C}$ for $15 \mathrm{~min}$ before addition of $\mathrm{CCl}_{4}$ (final volume $3.0 \mathrm{ml}$, $30 \mathrm{mM} \mathrm{CCl}_{4}$, containing $25 \mu \mathrm{Ci}\left[{ }^{14} \mathrm{C}^{-C_{C C l}}\right)$. Under the conditions of incubation (succinate, ADP and nitrogen atmosphere), the affinity of mitochondrial cytochrome oxidase is sufficiently high to reduce the dissolved oxygen concentration below $5 \cdot 10^{-8}[10]$. Following $30 \mathrm{~min}$ of anaerobic incubation, mitochondria were sedimented and washed, and mtDNA was prepared. Incubations containing calf thymus nDNA were extracted with chloroform-isoamyl alcohol (20:1) and purified as described.

\section{Radioactivity measurements}

Radioactivity was determined using ACS scintillation cocktail and a Packard liquid scintillation spectrometer. Determinations were corrected for quench and converted to mole values based on the specific activity of $\left[{ }^{14} \mathrm{C}_{C} \mathrm{CCl}_{4}\right.$. DNA was measured by absorbance at $260 \mathrm{~nm}$ using $1 . A$ unit $=50 \mu \mathrm{g} / \mathrm{ml}$ DNA.

\section{RESULTS}

Binding of $\mathrm{CCl}_{4}$ metabolites to rat liver $\mathrm{DNA}$

Table I illustrates that at the low dose of $\mathrm{CCl}_{4}$, hepatic mtDNA bound about 20

TABLE I

BINDING OF $\mathrm{CCl}_{4}$ METABOLITES TO DNA IN VIVO

\begin{tabular}{lclll}
\hline Dose & Time (h) & $\begin{array}{l}\text { pmol CCl metabolite/ } \\
\text { mg mtDNA }\end{array}$ & $\begin{array}{l}\text { pmol } \mathrm{CCl}_{4} \text { metabolite/ } \\
\text { mg nDNA }\end{array}$ & $\begin{array}{l}\text { Binding ratio: } \\
\text { mtDNA binding/ } \\
\text { nDNA binding }\end{array}$ \\
\hline $2 \mu \mathrm{l} / \mathrm{kg}$ & 5 & $1.9 \cdot 10^{1}$ & $7.1 \cdot 10^{-1}$ & 27 \\
$2 \mu \mathrm{l} / \mathrm{kg}$ & 24 & $2.5 \cdot 10^{1}$ & $5.0 \cdot 10^{-1}$ & 50 \\
$1.1 \mathrm{ml} / \mathrm{kg}$ & 24 & $5.1 \cdot 10^{3}$ & $2.4 \cdot 10^{2}$ & 21 \\
\hline
\end{tabular}


TABLE II

BINDING OF $\mathrm{CCl}_{4}$ METABOLITES TO DNA IN VITRO

\begin{tabular}{|c|c|c|}
\hline Sample & $\begin{array}{l}\text { nmol } \mathrm{CCl}_{4} \text { metabolite } \\
\text { mg DNA }\end{array}$ & $\begin{array}{l}\text { mol CCl}_{4} \text { metabolite/ } \\
\text { mol DNA bases }\end{array}$ \\
\hline $\mathrm{mtDNA}^{\mathrm{b}}$ & $6.2 \pm 1.5$ & $1.9 \cdot 10^{-3}$ \\
\hline $\mathrm{mtDNA}+\mathrm{PMS}^{\mathrm{c}, \mathrm{d}}$ & $6.0 \pm 1.8$ & $1.8 \cdot 10^{-3}$ \\
\hline nDNA $^{\circ}$ & $0.8 \pm 0.09$ & $0.2 \cdot 10^{-3}$ \\
\hline $\mathrm{nDNA}+\mathrm{PMS}^{\mathrm{c}, \mathrm{d}}$ & $3.3 \pm 0.7$ & $1.0 \cdot 10^{-3}$ \\
\hline
\end{tabular}

${ }^{\mathrm{a}}$ Calculation based on $3.237 \mu \mathrm{mol}$ nucleotides/mg DNA [7].

${ }^{b}$ Mean of 4 experiments \pm standard deviation.

Mean of 3 experiments \pm standard deviation.

"PMS, post-mitochondrial fraction prepared as described.

pmol/mg DNA. Hepatic nDNA binding was only $2-4 \%$ of mtDNA binding on a nucleotide of DNA basis. At the acutely toxic $\mathrm{CCl}_{4}$ dose, $5 \cdot 10^{3} \mathrm{pmol} / \mathrm{mg} \mathrm{mtDNA}$ was bound, which was 20 -fold greater than the binding to nDNA. Thus, while binding to both nDNA and mtDNA increased with increased dose of $\mathrm{CCl}_{4}, \mathrm{mtDNA}$ bound $20-50$-fold more radioactivity than nDNA at both low and high dose levels.

Binding of $\mathrm{CCl}_{4}$ metabolites to rat liver mtDNA following incubation of isolated mitochondria

After incubation of isolated rat hepatic mitochondria and $\left[{ }^{14} \mathrm{C}\right] \mathrm{CCl}_{4}$, radioactivity was bound to mtDNA (Table II). Addition of the post-mitochondrial supernatant fraction did not increase the binding. This suggests that the metabolic pathway for activation of $\mathrm{CCl}_{4}$ to the binding metabolite may be present in the mitochondrial fraction. Binding of radioactivity to calf thymus DNA in the presence of $\left[{ }^{14} \mathrm{C}_{\mathrm{CCl}} \mathrm{Cl}_{4}\right.$ was greatly stimulated by the inclusion of the post-mitochondrial supernatant fraction in the incubation.

\section{DISCUSSION}

We have shown that measurable binding of radioactivity from $\left[{ }^{14} \mathrm{C}_{\mathrm{CCl}}\right.$ to mtDNA occurred in vivo after a single exposure to $\mathrm{CCl}_{4}$. The degree of binding increased with the dose of $\mathrm{CCl}_{4}$ and the binding was 20-50-fold greater to mtDNA

TABLE III

AVERAGE NUMBER OF DNA BASES MODIFIED BY $\mathrm{CCl}_{4}$ METABOLITES

\begin{tabular}{lcll}
\hline Dose & Time $(\mathrm{h})$ & miDNA & nDNA \\
\hline $2 \mu \mathrm{l} / \mathrm{kg}$ & 5 & 1 in 170000 & 1 in 4600000 \\
$2 \mu \mathrm{l} / \mathrm{kg}$ & 24 & 1 in 130000 & 1 in 6500000 \\
$1.1 \mathrm{ml} / \mathrm{kg}$ & 24 & 1 in 640 & 1 in 13000 \\
\hline
\end{tabular}


than to nDNA. The binding of the $\mathrm{CCl}_{4}$ metabolite to mtDNA appeared to be covalent, as the radioactivity remained after the mtDNA had been purified by treatment with detergent, digestion with RNase and protease, extraction with organic solvents, dialysis, and density gradient centrifugation in high-molarity $\mathrm{CsCl}$. These treatments would be expected to remove non-covalently bound radioactivity, and radioactivity associated with protein, RNA, and lipids. The stoichiometry of binding to DNA is shown in Table III. By expressing the results reported in Table I in terms of mol nucleotides/mol $\mathrm{CCl}_{4}$ metabolite bound, it is seen that at the low level of $\mathrm{CCl}_{4}$ exposure, only 1 base out of $1.3 \cdot 10^{5}$ would be expected to be modified in mtDNA. Since each molecule of mammalian mtDNA contains approx. $3.3 \cdot 10^{4}$ bases [11], only 1 out of every 4 mtDNA molecules would, on the average, contain a modified nucleotide. However, at the higher dosage, 1 out of every 640 nucleotides may be modified, affecting $4 \%$ of all mtDNA nucleotide base pairs.

The results of incubation of isolated hepatic mitochondria with $\mathrm{CCl}_{4}$ would indicate that mitochondria may have the ability to metabolize $\mathrm{CCl}_{4}$ to an active metabolite which is capable of binding to mtDNA. Mitochondria isolated as described, routinely contain less than $3 \%$ contamination by microsomes [12]. Thus, it is not likely that the activation of $\mathrm{CCl}_{4}$ seen is due to microsomal contamination. Further evidence against microsomal involvement is the failure to increase mtDNA binding upon addition of active post-mitochondrial supernatant fraction.

Hepatic mitochondria contain a cytochrome P-450 system capable of hydroxylating steroids [16]. This system may be capable of metabolizing $\mathrm{CCl}_{4}$, analogous to microsomal cytochrome P-450 [17]. Also, dehalogenation of allyl chloride [18] and halothane [19] can be catalyzed by reduced hemin. Whatever the route, these results suggest that $\mathrm{CCl}_{4}$, like benzene [4] and aflatoxin $\mathrm{B}_{1}$ [3] may be metabolically activated by mitochondrial enzymes.

At the present, we do not know the significance of the high degree of disruption of mtDNA chemistry. The economy of organization of information in mtDNA [13] makes it extremely likely that modification of even a fraction of a percent of the mtDNA sequence will have a functional consequence on mtDNA replication, transcription, or translation. However, the recovery of mitochondrial function after acute $\mathrm{CCl}_{4}$ intoxication [8] suggests that the binding to mtDNA does not play a role in $\mathrm{CCl}_{4}$-induced hepatotoxicity. The effects may be more subtle and delayed in expression. For many years the question of the involvement of mitochondria in the process of transformation and malignancy has been discussed (for review, see [14]). Birky [20] discussed mechanisms by which clones of cells with modified mtDNA can arise. Neubert et al. [15] has proposed a mechanism by which modification of a small portion of the mitochondrial population can lead to a malignant cell. However, an understanding of the role of mitochondrial xenobiotic activation and of mtDNA in chemical carcinogenesis awaits futher investigation. 


\section{ACKNOWLEDGEMENTS}

We thank Dr. R.C. Conolly and Dr. R.J. Richardson for their helpful discussions while conducting this work. We also gratefully acknowlege Dr. Conolly's analysis of the purity of $\left[{ }^{14} \mathrm{C}\right] \mathrm{CCl}_{4}$ by gas chromatography. We thank Katherine Milliken for her assistance in the preparation of this manuscript. GNL is a post-doctoral trainee on PHS ES07062 NIEHS.

\section{REFERENCES}

1 J.M. Backer and I.B. Weinstein, Interaction of benzo(a)pyrene and its dihydrodiol-epoxide derivative with nuclear and mitochondrial DNA in C3H10T1/2 cell cultures, Cancer Res., 42 (1982) 2764-2769.

2 J.A. Allen and M.M. Combs, Covalent binding of polycyclic aromatic compounds to mitochondrial and nuclear DNA, Nature, 287 (1980) 243-245.

3 B.G. Niranjan, N.K. Bhat and N.G. Avadhani, Preferential attack of mitochondrial DNA by aflatoxin $B_{1}$ during hepatocarcinogenesis, Science, 215 (1982) 73-75.

4 G.F. Kalf, T. Rushmore and R. Snyder, Benzene inhibits RNA synthesis in mitochondria from liver and bone marrow, Chem.-Biol. Interact., 42 (1982) 353-370.

5 B.G. Niranjan and N.G. Avadhani, Activation of aflatoxin $B_{1}$ by a mono-oxygenase system localized in rat liver mitochondria, J. Biol. Chem., 255 (1980) 6575-6578.

6 M.I. Diaz-Gomez, and J.A. Castro, Binding of carbon tetrachloride metabolites to liver nuclear DNA, proteins, and lipids, Toxicol. Appl. Pharmacol., 56 (1980) 199-206.

7 G.N. Levy, and M.J. Brabec, Interaction of carbon tetrachloride with rat liver mitochondrial DNA, Toxicologist, 3 (1983) 100.

8 M.J. Brabec, R.H. Gray and I.A. Bernstein, Restoration of hepatic mitochondria during the recovery from carbon tetrachloride intoxication, Biochem. Pharmacol., 23 (1974) 3227-3238.

9 H.V. Gelboin, A microsome-dependent binding of benzo(a)pyrene to DNA, Cancer Res., 29 (1969) $1272-1276$.

10 N. Oshino, T. Sugano, R. Oshino and B. Chance, Mitochondrial function under hypoxic conditions: the steady state of cytochrome $\mathrm{A}+\mathrm{A} 3$ and their relation to mitochondrial energy states, Biochim. Biophys. Acta, 368 (1964) 298-310.

11 D.A. Clayton, Replication of animal mitochondrial DNA, Cell, 28 (1982) 693-705.

12 M.J. Brabec, R.K. Brabec and R.H. Gray, Contamination by rough microsomes of rat liver mitochondria during poisoning by carbon tetrachloride, Micron, 10 (1979) 167-168.

13 P. Borst and L.A. Grivell, Small is beautiful - portrait of a mitochondrial genome, Nature, 290 (1981) 443-444.

14 P.L. Pederson, Tumor mitochondria and the bioenergetics of cancer cells, Prog. Exp. Tumor Res., 22 (1978) 190-274.

15 D. Neubert, W. Hopfenmuller and G. Fuchs, Manifestation of carcinogenesis as a sluchastic process on the basis of an altered mitochondrial genome, Arch. Toxicol., 48 (1981) 89-125.

16 J.I. Pederson, J. Bjorkhem and J. Gustaffson, 26-Hydroxylation of C27-steroids by soluble liver mitochondrial cytochrome P-450, J. Biol. Chem., 254 (1979) 6464-6469.

17 E.A. Glende, Carbon tetrachloride-induced protection against carbon tetrachloride toxicity: Role of the liver microsomal drug metabolizing system, Biochem. Pharmacol., 21 (1972) 1697-1702.

18 C.E. Castro, The rapid oxidation of Iron (II) porphyrins by alkyl halides. A possible mode of intoxication of organisms by alkyl halides, J. Am. Chem. Soc., 86 (1964) 2310-2311.

19 M. Baker and R.A. Van Dyke, Reduction of halothane by heme and heme protein, Fed. Proc., 42 (1983) 1143 .

20 C.W. Birky, Relaxed cellular controls and organelle heridity, Science, 222 (1983) 468-475. 